Maria Jolanta Olszewska

Instytut Literatury Polskiej, Uniwersytet Warszawski

\title{
Narodowy geniusz, czyli portret Fryderyka Chopina w Ostatnim koncercie Stanisławy Fleszarowej-Muskat
}

Od czasu, gdy się objawit, stuchamy w zadziwieniu, w olśnieniu, stuchamy ze tzami w oczach, my ojcowie, dziadowie nasi, my Polacy i wszyscy inni na wszystkich ziemiach i wyspach tego świata. [...] Jakże mówić o cudzie, którego ze tzami w oczach stuchamy, który nas glębią swą kotysze aż do samego dna pamięci narodowej i ludzkiej, i jeszcze innej, głębszej, niespodziewanej! [...] on jeden, tajemniczy odkrywca pamięci niepojętej, czulszej od wszystkich innych, pamięci, dla której braknie stów.

Juliusz Kaden-Bandrowski, Życie Chopina

Odpowiedź na pytanie: ,jak pisać o Fryderyku Chopinie?” [Boniecki 1991: 681] okazuje się niełatwa. Jego niezwykłe życie i dzieło twórcze szybko obrosło w legendę i przekształciło się w mit, który istnieje w kulturze polskiej od wielu lat, o czym świadczy ogromna liczba powstałych na ten temat tekstów o bardzo różnym charakterze.

Otóż jakkolwiek rozpatrywać i oceniać dyskurs o Chopinie, od blisko dwóch stuleci profilowany w podstawowej mierze przez rozmaitego rodzaju propozycje muzykologiczne, krytycznomuzyczne i biograficzne, nie sposób nie zauważyć, iż kształtują go również od dawna komentarze innego pokroju - literackie chopiniana [wyróż. - M.J.O.]. Ich bogatą historię otwiera sonet Do Fryderyka Chopin grajacego na fortepianie (1830) młodego Leona Ulricha, znanego dzisiaj co najwyżej z przekładów Szekspira. Lawina kolejnych utworów literackich ma swój początek jeszcze za życia kompozytora (na czele ze słynną „ekshibicjonistyczną powieścią” George Sand Lukrecja Floriani, 1846; wyd. pol. 2009), niewątpliwie przybiera na sile po 
jego śmierci (zapisy wspomnieniowe, w hołdzie geniuszowi, m.in. Zaduma i nokturno Bohdana Zaleskiego, Czarne kwiaty i Fortepian Szopena Norwida), później zaś zwłaszcza w latach rocznicowych (przede wszystkim w 1910 oraz 1949 roku). Wielu innym rocznicom chopinowskim zawdzięczają zresztą swoje powstanie tak różne utwory, jak Pamięci Chopina Jana Kasprowicza, Ku czci mistrza Stanisława Przybyszewskiego, Deszcz nad Paryżem Adama Zagajewskiego czy - ostatnio - Mały Chopin Michała Rusinka. Dwa stulecia przynoszą w istocie imponującą liczbę rozmaitych realizacji literackich (poetyckich, powieściowych, eseistycznych), które świadczą o wielkim zainteresowaniu autorów osobą i twórczością kompozytora, także o zmieniających się preferencjach i estetykach - ewolucji recepcji Chopina. [Hejmej 2010]

Tak więc dwa stulecia, które upłynęły od urodzin Fryderyka Chopina, przyniosły, co potwierdzają szczegółowe badania Kazimierza Maciąga czy Andrzeja Hejmeja, olbrzymią liczbę rozmaitych realizacji literackich (poetyckich, powieściowych, dramatycznych, eseistycznych). Mają one co prawda bardzo różną wartość, świadczą jednak o niesłabnącej fascynacji osobą i twórczością kompozytora, a także o ewolucji recepcji Chopina. Pokazują to liczne antologie poetyckie przygotowane przez: Krystynę Kobylańską (Chopin. Antologia Poetycka, 1949), Mieczysława Idzikowskiego i Bronisława Edwarda Sydowa (Portret Chopina. Antologia ikonograficzna, 1963), Edmunda Słuszkiewicza (Wiersze o Chopinie. Antologia i bibliografia, 1964), oraz wybory na prawach antologii: Mieczysława Żukowskiego (Fryderyk Chopin w świetle poezji polskiej, 1910), Franciszka Barańskiego (Chopin w poezji polskiej, rkp.), Krzysztofa Jeżewskiego (Chopin w poezji polskiej, 1999), Ireny Chyły-Szypułowej (Poezja polska $w$ darze Chopinowi, 2003) czy Marii Cieśli-Korytowskiej (Aneks, 2004 [zob. Cieśla-Korytowska 2004]. Każdy z autorów wypracował własny styl pisania o Chopinie i jego muzyce zdeterminowany czasem historycznym, w którym tworzył [Poniatowska 2001]. Przez lata konsekwentnie budowana legenda artysty w pamięci pokoleń utrwaliła jego wizerunek jako genialnego kompozytora i Polaka. 
Wśród niezwykle obfitej i zróżnicowanej twórczości Stanisławy Fleszarowej-Muskat (1919-1989), bardzo poczytnej pisarki z okresu PRL-u, znajdują się dwa utwory dramatyczne, których bohaterem jest Chopin. Wcześniej jednak zrealizowano słuchowiska: Chopin i Zuźka: sztuka w 3 aktach (1949, fragment zostal przedrukowany w „Rejsach”), a następnie Ostatni koncert (1960), za które pisarka otrzymała pierwszą nagrodę Polskiego Radia przyznaną za utwór radiowy związany z życiem i dziełem Chopina.' Wkrótce to słuchowisko Fleszarowa-Muskat przekształciła w dramat sceniczny, który opatrzony uwagami Bronisława Nycza ukazał się drukiem w roku 1965. Praktycznie jest to dzieło nieznane szerszemu ogółowi, chociaż powstawało z myślą o takiej właśnie publiczności, doskonale realizując strategię pisarską autorki Tak trzymaćn.

Chociaż krytyka nie zawsze była przychylna Fleszarowej-Muskat, to jednak jej powieści, opowiadania i twórczość dramaturgiczno-radiowa cieszyły się dużą popularnością wśród ówczesnych odbiorców, osiągając w sumie prawie milionowy nakład. Niewątpliwie w czasach PRL-u jej pisarstwo było fenomenem, o czym piszą Mariola Stołek-Nawrocka i Krystyna Świerkosz. Źródłem tej poczytności był sposób, w jaki pisała. Promowany przez danego pisarza model literatury wynika z akceptowanej przez niego określonej wizji świata i kultury. W przypadku Fleszarowej-Muskat zarówno światoobraz, jak i forma artystyczna mają charakter wartościujący [Burek 1987: 145]. Wyróżniający jej utwory tradycjonalizm formalny, a przy tym znakomite wyczucie problematyki

1 Pierwowzorem dramatu było słuchowisko Ostatni koncert nadawane w radiu w roku 1960 [zob. Fleszarowa-Muskat 1960a]. Następnie powstał dramat Ostatni koncert opublikowany najpierw w czasopiśmie „Dialog” [zob. Fleszarowa-Muskat 196ob], a pięć lat później jako wydanie osobne [zob. Fleszarowa-Muskat 1965].

Fundacja im. Stanisławy Fleszarowej-Muskat wraz z Towarzystwem Przyjaciół Sopotu 21 października 2019 roku urządziła wieczór teatralny w dworku Sierakowskich w Sopocie. W programie wieczoru znalazło się wystąpienie Ewy Nawrockiej poświęcone dramatowi Ostatni koncert; następnie wyświetlono fragment przedstawienia teatralnego dramatu w wykonaniu aktorów Teatru Wybrzeże: Agaty Woźnickiej (Zuzka) i Michała Kowalskiego (Chopin). Całość zakończyła rozmowa Ewy Nawrockiej z Krystyną Łubieńską, aktorką Teatru Wybrzeże, występującą w sztukach i słuchowiskach Fleszarowej-Muskat. Z kolei w dniach 23-24 października 2019 roku w Muzeum Sopotu odbyła się konferencja Stanisława Fleszarowa-Muskat i jej wspótcześni. 
mogącej zainteresować szerokie grono odbiorców, wartka akcja, przekonujące kreacje bohaterów, z którymi przeciętny czytelnik mógł się łatwo i chętnie identyfikować, barwny styl wypowiedzi, wyrazisty system aksjologiczny - te cechy sprawiają, że dzieła Fleszarowej-Muskat są „swoistym świadectwem współczesnego obyczaju" [S.J. 1968]. Autorka z przekonaniem realizowała ten typ literatury, w którym nacisk został położony na odbiór. Jej teksty sytuują się na pograniczu powieści psychologiczno-obyczajowych i melodramatu. W tym przypadku mamy do czynienia z prezentacją wielkich, historycznych wydarzeń z perspektywy zwyczajnych ludzi, przy czym Fleszarowa-Muskat doskonale potrafiła odtworzyć klimat opisywanych przez siebie czasów i przybliżyć przeciętnemu odbiorcy daną historię. Zazwyczaj swą uwagę skupiała na codziennych, ludzkich problemach i osobistych dramatach, przekonująco poruszała tematy międzyludzkich uczuć, a zwłaszcza miłości i przeszkód, jakie stają na drodze do jej realizacji.

Sztuka pisarska Fleszarowej-Muskat, a dotyczy to także jej działalności dramatopisarskiej, sytuuje się zatem na pograniczu literatury wysokoartystycznej i popularnej, ze wskazaniem na tę drugą. $Z$ tego powodu jej utwory należy odczytywać z „perspektywy osmozy” [Dec 1992: 68]. Taką też należałoby przyjąć perspektywę badawczą, analizując Ostatni koncert. Wbrew pozorom nie jest to jednak sprawa prosta, chociażby ze względu na nieostrość semantyczną pojęcia literatury popularnej [Kubikowski 1965: 24]. Trzeba wziąć pod uwagę, że

każda próba ustalenia sztywnej granicy między literaturą popularną, masową a literaturą „wysokoartystyczną” bez ustalenia odpowiednio wielkiego dystansu czasowego, będzie kłopotliwa i nie w pełni obiektywna. Płynność granicy intuicyjnej również nie pomaga popularnym tekstom w przebijaniu się przez opór uprzedzeń i nie zawsze jasnych deprecjacji, przez co skazane są one długo na trwanie w cieniu krytycznoliterackich obiekcji - nieraz oczywiście uzasadnionych. Literatura popularna uczy badaczy, wnikliwych czytelników, niezbędnej ostrożności, przy zachowaniu której czytelnik będzie umiał odnaleźć odpowiednią ostrość widzenia rzeczy takimi, jakimi 
są w swej istocie. Ta ostrożność to unikanie z góry przyjętych granic jako kategorii waloryzujących bądź deklasujących tekst, a tym samym zniekształcających jego prawdziwe kształty. [Korotkich 2020: 10]

Nie chodzi zatem o porównywanie i zestawianie ze sobą różnych tekstów skierowanych do dwóch odmiennych kręgów odbiorczych, tylko o zaakceptowanie faktu, że utwory z kręgu literatury popularnej stanowią odrębne zjawisko o charakterze literackim, kulturowym i społecznym. Ze względu na rolę odbiorcy w kształtowaniu formy wypowiedzi, który nie pozostaje w tym przypadku neutralny, badacze podkreślają społeczne znaczenie kultury popularnej. Podczas analizy wymusza to konieczność wzięcia pod uwagę kwestii związanych z socjologią literatury. W tekstach dających się zakwalifikować do literatury popularnej, stających się nośnikiem określonej ideologii społecznej funkcja komunikacyjna zazwyczaj dominuje nad poznawczą, co dobrze widoczne jest w całej twórczości Fleszarowej-Muskat. Ważny okazuje się dla niej sposób przekazywania informacji. To tłumaczy jej dążenie do upraszczania struktur świata przedstawionego, poddanego ewaluacji po to, aby uczynić go nośnikiem określonej ideologii, tak aby dany tekst mógł funkcjonować w danej rzeczywistości społecznej. Pisarka nigdy nie eksperymentowała z formą i językiem, tylko budowała dyskurs oparty na zasadzie porozumienia autora z odbiorcą masowym. Podobnie dzieje się w przypadku Ostatniego koncertu, w którym nie mamy do czynienia z subtelną, wyrafinowaną grą intelektualną prowadzoną z odbiorcą, obecną chociażby w Lecie $w$ Nohant Jarosława Iwaszkiewicza. Interesujący nas dramat Fleszarowej-Muskat należy do tekstów, które zazwyczaj balansują na pograniczu oryginalności i stereotypowości. Budują rzeczywistość alternatywną, co prawda bardzo bliską realnemu światu, ale jednak pozwalającą na zaspakajanie głodu emocji czytelnika i w związku z tym na wynagradzanie siebie za różne braki we własnym życiu postrzeganym jako nieudane. Literatura popularna, podobnie jak literatura wysokoartystyczna, podejmuje ważne kwestie, na które odbiorca otrzymuje uproszczone odpowiedzi. Przy czym głównym kryterium doboru tematyki pozostaje popularność tematu. W przypadku utworów 
Fleszarowej-Muskat nie mamy, co prawda, do czynienia z formą heurystyczną, jednak nie oznacza to, że pisarka nie miała zdolności tworzenia figur myślowych - takich, które pozwoliłyby jej na dociekanie prawdy o rzeczywistości i ludzkiej egzystencji.

Ważnym celem działań twórczych podejmowanych przez autorkę Lata nagich dziewcząt było uporządkowanie i wpisanie w czytelne ramy określonego systemu wartości, co miało pozwolić jej na zbudowanie wspólnoty odbiorczej. Istotne w tym przypadku było zakorzenienie danego obrazu w świadomości społecznej. $\mathrm{Z}$ tego powodu pisarka w przekonujący sposób musiała zaapelować do wiedzy, doświadczeń i wrażliwości odbiorcy w celu uświadomienia mu roli kontekstu kulturowego. $\mathrm{Z}$ tego też powodu tak ważną funkcję w konstruowaniu jej tekstu, zresztą tak jak w całej literaturze popularnej, pełnią stereotypy, kalki i schematyzmy, mające moc organizowania ludzkich zachowań [Schaff 1981: 36, 13]. Budują one określony porządek społeczny, co pozwala na stabilizację obrazu świata zgodnie z obowiązującymi w nim normami oraz na jego uspójnienie [Mitosek 1974: 13-17]. W ten sposób stają się one podstawowym ideologicznym składnikiem dyskursu. Tak więc podsumowując te rozważania, trzeba stwierdzić, że to kategorie socjologiczne w połączeniu $\mathrm{z}$ etycznymi i aksjologicznymi determinują zarówno treść, jak i strukturę tekstu w utworach Fleszarowej-Muskat, opartą na skonwencjonalizowanych środkach ekspresji artystycznej. Zasada „popularności”, której są one podporządkowane, okazuje się czynnikiem je waloryzującym, wpływającym na proces ich odbioru i stopień uwrażliwienia odbiorcy. Omówioną powyżej zasadę popularności Fleszarowa-Muskat z powodzeniem realizowała w całej swej twórczości. Warto z tej perspektywy badawczej dokonać interpretacji Ostatniego koncertu. W tym kontekście rodzi się pytanie o ideologizację treści, miejsca, czasu i postaci dramatu.

Kiedy pisarka zamieszkała na Wybrzeżu, zajęła się pracą zawodową w różnych instytucjach kulturalnych. Pracowała m.in w radiu oraz jako kierownik literacki, najpierw Teatru Wybrzeże (19501953), a potem Estrady (1953-1955). Z tego chociażby powodu mogła dobrze poznać scenę od strony praktycznej. Celem działań teatralnych Fleszarowej-Muskat nie było eksperymentowanie - doskonale 
poruszała się $\mathrm{w}$ świecie konwencjonalnym. Promowała model teatru popularnego, w ramach którego pragnęła połączyć cele edukacyjne z rozrywkowymi. Odbiór sztuki miał pełnić w tym przypadku funkcję zarówno poznawczą, jak i terapeutyczną. Wśród wielu zagadnień, które pisarka podejmowała w swych utworach dramatycznych, pojawił się temat związany z artystą i artyzmem. Bohaterem dwóch poświęconych tej kwestii słuchowisk uczyniła młodego Chopina. W twórczy sposób w ramach konwencji obowiązującej w literaturze popularnej, odniosła się do utrwalonej w kulturze legendy artysty. Legenda biograficzna, będąca matrycą omawianego dramatu, rządzi się własnymi prawami, dlatego miała wpływ na treść, formę i styl Ostatniego koncertu. Rzecz dzieje się w ciągu jednego dnia, tuż przed wybuchem powstania listopadowego. Fabuła skoncentrowana jest wokół koncertu Chopina w Warszawie, który odbył się 11 października 1830 roku w Teatrze Wielkim. Był to ostatni występ kompozytora przed jego wyjazdem do Francji. Wkrótce, 2 listopada, Chopin opuścił stolicę Królestwa Polskiego, aby nigdy już do niej nie powrócić. Niedługo po jego wyjeździe, 29 listopada, wybuchła insurekcja. A zatem jest to moment szczególny, przełomowy zarówno dla Fryderyka, jak i jego bliskich oraz społeczeństwa polskiego. Tło niepodległościowe jest ważne, ponieważ uwypukla związki losów Chopina z losami Ojczyzny oraz nadaje jego muzyce wymiar patriotyczny i rewolucyjny.

Pisarka nie prowadziła własnych badań na temat życia Chopina. Wiadomości czerpała „z drugiej ręki”, nie poddając ich specjalnej weryfikacji. Kiedy pisała Ostatni koncert, istniała już obfita proza biograficzna, łącząca w obrębie swej struktury elementy biografii, literatury faktu i powieści historycznej, a zatem posiadająca charakter hybrydowy. Wśród tego typu prac warto przypomnieć znaczące tytuly, m.in. Chopin: czlowiek i artysta (1922) Jamesa Hunekera, Życie Chopina (1938) Juliusza Kadena-Bandrowskiego, Fryderyk Szopen (1938) i późniejszy Chopin (1949) Jarosława Iwaszkiewicza czy Ksztatt miłości (1950-1951) Jerzego Broszkiewicza. Prace te zawierają ważny materiał biograficzny i jednocześnie stanowią cenne źródło wiedzy na temat epoki, w której żył i tworzył kompozytor. Stają się także świadectwem ówczesnego sposobu rozumienia i interpretowania Chopina i jego dzieła. W każdej z tych książek 
został dowartościowany wczesny etap życia kompozytora, czyli czas do jego wyjazdu z Warszawy w roku 1830, kiedy kształtował się jako człowiek i artysta. Doznania ideowe, estetyczne i emocjonalne Chopina z przedpowstaniowej ojczyzny odcisnęły piętno na jego sylwetce twórczej. Ważnym źródłem wiedzy o kompozytorze $\mathrm{z}$ okresu warszawskiego jest wspomniana w przypisach do książkowego wydania Ostatniego koncertu praca pt. Młodość Chopina Adolfa Nowaczyńskiego z roku 1938, rok później wydana przez Towarzystwo Wydawnicze „Rój”, a wznowiona w roku 1948. Warto przypomnieć, że książkę Nowaczyńskiego poprzedził szereg artykułów poświęconych młodości kompozytora rekonstruowanej na podstawie wspomnień Oskara Kolberga, z którego rodziną młody Fryderyk był mocno zaprzyjaźniony. Nowaczyński był twórcą niepokornym, więc napisana przez niego barwna opowieść biograficzna odchodzi od konwencji legendowej. Pisarz wyszedł z założenia, że do tej pory

Sto piór jego życioobieg opisywało, z czego dziewięćdziesiąt odpisywało i przepisywało. Na pytanie: czemu? - odpowiedzieć się godzi: a bo go izolowali i zamykali w ciasnym kolisku jedynie z muzyką skuzynowanych i muzyką się parających, zapominając do cna, że to był nie tylko muzykus, muzykant, komponista, ale jednak geniusz. Wiadoma zaś rzecz, że taki jak stwierdzono geniusz [...] nie może się zajmować jedynie muzyką i muzykantami, ale musi, wyraźnie musi w młodości wieku przynajmniej zajmować wszystkim, po prostu wszystkim i wyrabiać sobie wyobrażenie o wszystkim, wiedzieć o wszystkim, wchłaniać wszystko, uczyć się wszystkiego. [Nowaczyński 1948: 91-92]

Na takie podejście Nowaczyńskiego do biografizmu prawdopodobnie miała wpływ kampania publicystyczna Tadeusza Boya-Żeleńskiego, który w skandalizującym zbiorze felietonów pt. Brązownicy (1930) domagał się demitologizującego odczytania biografii wielkich Polaków, uznając to za ważne posunięcie o charakterze demaskatorskim i jednocześnie kulturotwórczym. Wynikało ono z jego stosunku do polskiego romantyzmu. Nowaczyński wielokrotnie 
upominal się o prawdę o Chopinie jako o twórcy i człowieku, pokazaną w szerszym kontekście historycznym. Dlatego nalegał na gromadzenie pełnej dokumentacji źródłowej, a zwłaszcza na poszukiwanie listów kompozytora do różnych korespondentów czy sztambuchów z epoki. Te działania - jego zdaniem - umożliwiłyby rekonstrukcję kompletnej wiedzy na temat kompozytora. Wybór materiału i sposób jego prezentacji Nowaczyński uważał za istotne, o czym wcześniej już pisal chociażby w $O$ dramacie $z$ przeszłości (1906). Był zwolennikiem innej wizji historii niż ta, którą promował Henryk Sienkiewicz - wizję noblisty uznawał za jednostronną, a przez to fałszywą.

W Młodości Chopina wykorzystał i twórczo przekształcił wspomnienia z lat młodości starego Oskara Kolberga (przyjaciela Fryderyka), który pełni w powieści funkcję świadka epoki. Przeciwstawił się w ten sposób - do czego sam się przyznawał - koncepcji Stanisława Tarnowskiego, wyłożonej w pracy Chopin i Grottger. Dwa szkice (1892), dla którego muzyka Chopina była kwintesencją polskości, a sam kompozytor w jego przekonaniu powinien zostać uznany za „za czwartego wielkiego poetę Polski” [Tarnowski 1892: 8]. Nowaczyński w swej książce, mającej charakter gawędy, zrekonstruował ciekawe tło historyczne, odmalowując wszechstronny obraz życia w Warszawie w pierwszych latach istnienia Królestwa Polskiego. Tak więc w jego przypadku opowieść o dzieciństwie i młodości Chopina nie ogranicza się do prezentacji „suchych” faktów historycznych interpretowanych zgodnie z zasadami pozytywizmu. Nowaczyński ze znawstwem erudyty i dokumentalisty, a nawet satyryka stworzył barwny fresk rodzajowy, dostarczając odbiorcy szczegółowej wiedzy o epoce, w której żył i tworzył młody Fryderyk. Udało mu się odtworzyć koloryt tamtego świata z jego realiami i obyczajami. Po mistrzowsku oddał atmosferę Warszawy lat 20. i 30. XIX wieku. Materia o charakterze historycznym i biograficznym została przez pisarza przekształcona $\mathrm{w}$ dyskurs o charakterze gawędowym. Opierając się na wspomnieniach Kolberga, opowiadał o życiu rodzinnym Chopinów, wprowadzał barwną postać służącej Zuski, przypominał pierwszych nauczycieli i mistrzów Fryderyka. Drobiazgowo rekonstruował genealogię rodu Chopinów, pisał o narzeczeństwie rodziców muzyka, jego 
dzieciństwie, młodości, pierwszych publicznych występach i kompozycjach, jego przyjaźniach i pierwszych miłosnych zauroczeniach itd. Całość zakończył opisem koszmarnego snu, który miał Chopin ostatniej nocy przed wyjazdem z Warszawy. Nowaczyński nie starał się przekształcić anegdoty biograficznej w legendę hagiograficzną Chopina, ani dla odmiany budować jego antylegendy po to, aby ujawniać wstydliwe fakty z życia artysty, tak jak zrobił to Boy-Żeleński w biografii Mickiewicza. Chcial tylko zaprezentować kompozytora z jednej strony jako wybitnego, ponad przeciętność wrażliwego, ciekawego świata, życzliwego ludziom i szlachetnego artystę, ale z drugiej strony także jako człowieka „z krwi i kości”. Tak więc pisarz przestrzegal zasad zachowania wiarygodności faktów, czyli rygoru historycznej prawdy, ponieważ mówił o historii poświadczonej w różnych źródłach historycznych, i jednocześnie pisał opowieść przeznaczoną dla szerszego grona odbiorców, co $\mathrm{z}$ kolei wpłynęło na obecną w niej optykę historycznospołeczną.

Fleszarowa-Muskat wydaje się kroczyć podobną drogą jak Nowaczyński. Tekst Ostatniego koncertu, na który składają się materiały „z drugiej ręki”, przekształca konwencję popularnego dramatu historycznego ukazującego postać narodowego bohatera, co w przypadku literatury popularnej raczej nie jest czymś zaskakującym. Pisarka, o czym była już mowa, nie prowadziła osobnych badań, tylko bazowała na wiedzy, którą czerpała z dostępnej literatury przedmiotu, stosując przy tym chwyty skodyfikowane przez tradycję i utrwalone przez literaturę popularną. Stworzone przez nią postacie wywodzą swój rodowód z dramatów historycznych, a nawet $\mathrm{z}$ melodramatu czy wodewilu. Jednocześnie Fleszarowa-Muskat ujawniła w tej sztuce dobre wyczucie sceny. Wybrała epizod z życia Chopina o charakterze przełomowym: 11 października 1830 roku -przeddzień wyjazdu artysty do Paryża, a zarazem dzień jego ostatniego występu, podczas którego wykonał koncert fortepianowy e-moll. Wydarzenie to, jak się okazało, kończyło w życiu Chopina pewien etap i zapowiadało następny - było więc dla niego punktem zwrotnym. W omawianej sztuce sytuuje się ono w centrum fabuły, stając się punktem odniesienia dla wszystkich zdarzeń rozgrywających się na scenie w ciągu tego ważnego dla kompozytora dnia. W swych rozmowach bohaterowie nieustannie powracają do tego tematu: 
LUDWIKA No, cóż ostatni koncert Chopina w Warszawie.

P.MIKOŁAJ Ostatni koncert, powiadasz?

LUDWIKA Ostatni koncert przed wielką podróżą.

[Fleszarowa-Muskat 1965: 11] ${ }^{3}$

Strona formalno-kompozycyjna w sztuce Fleszarowej-Muskat przez luźny, traktowany po epicku układ aktów i scen realizuje konwencję „kroniki scenicznej”, w której została zachowana chronologia czasowa: akcja toczy się od poranka do wieczora, z punktem kulminacyjnym, jakim jest wspomniany już uroczysty koncert ${ }^{4}$. Akt I rozgrywa się w mieszkaniu Chopinów w Warszawie w pałacu Krasińskich przy Krakowskim Przedmieściu na rogu ul. Traugutta, w przytulnie urządzonym saloniku, gdzie główne miejsce zajmuje fortepian $\mathrm{z}$ otwartą klawiaturą. Ma to znaczenie symboliczne ze względu na aluzję do słynnego poematu Cypriana Kamila Norwida (Fortepian Chopina). Znajdują się tu także schody, które prowadzą „na górkę”, gdzie sypia i pracuje Chopin. Nie jest to jednak - tak jak zauważa Fleszarowa-Muskat - zgodne z prawdą historyczną, ponieważ w rzeczywistości tam właśnie znajdowały się drzwi. W trakcie przedstawienia stamtąd będą dochodzily dźwięki muzyki, co należy potraktować jako ważny i jednocześnie ciekawy gest sceniczny. Przez mieszkanie Chopinów przewijają się różne osoby, członkowie najbliższej rodziny: pan Mikołaj, pani Justyna, siostry, Ludwika i Izabela, służba, w tym Zuska, ulubiona służąca Chopinów; goście: Wojciech Żywny - nauczyciel Fryderyka, Wilhelm, Antoni i Oskar Kolbergowie - przyjaciele domu. Rozmawiają o bardzo różnych sprawach, tych błahych, związanych z życiem codziennym, pozornie mało ważnych, jak np. zakup podróżnego kuferka, pastowanie butów czy podawanie posiłków,

Warto przypomnieć, że Janina Siwkowska poświęciła tej tematyce powieść o charakterze popularnym: Pan Chopin opuszcza Warszawę (1958).

„Jeszcze nie umilkły oklaski, jakimi Warszawa przyjęła pierwszy z dwu koncertów, $f$-moll, zaprezentowany wczesną wiosną roku 1830 w Teatrze Narodowym, a dwudziestoletni kompozytor zaczął szkicować następny koncert, e-moll. Allegro maestoso (część pierwsza) powstało już w kwietniu, na Wielkanoc. Wydawało się Chopinowi lepsze niż Allegro z koncertu pierwszego. W maju ukończył Larghetto, które pisał w nastroju szczególnym. W połowie miesiąca zwierzał się Tytusowi Woyciechowskiemu: «Pomimo woli - przez oczy - wpadło mi coś do głowy i lubię się tym pieścić»” [Tomaszewski 2020]. 
a także o tych istotnych, jak narastające represje ze strony władz rosyjskich. Pisarka wbudowała w tekst swego dramatu apokryf rodzinny Chopinów. Wracają wspomnienia z młodości rodziców Fryderyka, przede wszystkim heroicznej przeszłości Mikołaja, który brał udział w insurekcji kościuszkowskiej, a później przez sześć lat pracował jako guwerner w domu Łączyńskich, aby następnie trafić do rodziny hrabiego Fryderyka Skarbka (17921866) - wybitnego ekonomisty, historyka i pisarza. Tam poznał ubogą krewną Skarbków, Teklę Justynę Krzyżanowską, obdarzoną talentem muzycznym. Zakochał się w niej i w roku 1806 ożenił się. W jego młode życie wpisały się osoby tak znaczące, jak: Jan Dekert (1786-1861), biskup sufragan warszawski, syn prezydenta Warszawy, zasłużonego reformatora z czasów Sejmu Czteroletniego; Maria z Łączyńskich Walewska (1786-1817), kochanka Napoleona i matka jego syna Aleksandra Walewskiego; Teodor Łączyński (1785-1842), brat Marii, oficer napoleoński; Jan Nepomucen Dziewanowski (1782-1808), szwoleżer spod Somosierry; wspomniany Skarbek.

Dowiadujemy się także, że od roku 1810 Chopinowie mieszkali w Warszawie - tam rozpoczęli wspólne, pełne trudów życie. Pan Mikołaj pracował w różnych szkołach jako nauczyciel języka francuskiego. Na świat przychodziły kolejne dzieci, a rodzinę Chopinów spotkała tragedia, kiedy na gruźlicę zmarła najmłodsza z rodzeństwa, Emilka. Jej wspomnienie jest dla wszystkich domowników wciąż żywe i bolesne. Mikołaj Chopin w sztuce Fleszarowej-Muskat prezentuje się jako człowiek szlachetny i prawy, dość jednak surowy, a Justyna jako osoba pełna ciepła i dobroci, kłopocząca się o wszystko i troskająca się o przyszłość swoich dzieci. W rozmowach, które mają miejsce w akcie I, zostaje przywołane dzieciństwo Fryderyka, lata spędzane w Żelazowej Woli, Warszawie, gdzie objawił się jego muzyczny talent, i na Kujawach, w rodzinnych stronach matki, gdzie po raz pierwszy zetknął się z muzyką ludową, która go zachwyciła. Fleszarowa-Muskat kreśli jego portret jako niezwykle wrażliwego, pełnego życia i humoru dziecka. Ze wzmianek pojawiających się w kolejnych rozmowach możemy odtworzyć okres jego nauki, wstępne próby kompozytorskie, koncerty publiczne, posługę organisty w kościele Wizytek, młodzieńcze przyjaźnie i oczarowania miłosne, pierwsze ważne 
zagraniczne wyjazdy do Drezna i Wiednia, uwieńczone towarzyskim i artystycznym sukcesem. Rodzina Chopinów w ujęciu Fleszarowej-Muskat jest szczęśliwa i zżyta. Fryderyk, uznany za cudowne dziecko, słabego jednak zdrowia, wzrastał więc w atmosferze domowego ciepła i życzliwości. Pisarka pokazała go jako dwudziestoletniego młodzieńca otoczonego miłością, wręcz rozpieszczanego i uwielbianego przez rodziców, siostry i służącą Zuskę, a jednocześnie dobrze wychowanego, szlachetnego i czarującego. Rozmowy w salonie, o czym była już mowa, przerywają dochodzące z pokoju Fryderyka dźwięki jego muzyki. Artysta ćwiczy rondo $\mathrm{z}$ koncertu e-moll, który miał za kilka godzin wykonać na

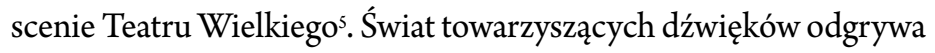
w tym spektaklu ważną rolę. Buduje odpowiednią atmosferę i jednocześnie przypomina, kto jest głównym bohaterem dramatu.

Akt II rozgrywa się w trakcie koncertu, za kulisami. Występ okazał się wielkim sukcesem ${ }^{6}$. Szczególnie istotne w tym akcie są sceny ukazujące spotkania kompozytora z ukochaną Konstancją Gładkowską. Autorka postrzega ją jako kobietę piękną i uzdolnioną,

5 "Część ostatnia Koncertu - Rondo - powstała nie bez oporów. [...] Przed wyjazdem należało zaś ukończyć nowy koncert, spróbować go i na koniec zaprezentować warszawskiej publiczności. W sierpniu ukończył więc Rondo. We wrześniu - na trzech przesłuchaniach w prywatnym gronie - sprawdził zaś brzmienie całości. Najpierw z kwartetem, następnie z małą orkiestrą. Mógł stwierdzić ze spokojem a nie bez dumy: «Rondo - efektowne. Allegro - mocne». Wreszcie w październiku przedstawił nowy swój koncert szerokiej publiczności, w Teatrze Narodowym" [Tomaszewski 2020].

6 „«Wczorajszy koncert udał mi się - pisał Chopin 12 października 1830 roku do Tytusa Woyciechowskiego. - Sala pełna!». «Kurier Warszawski» donosil, że «słuchaczów znajdowało się około 700». Oklaskiwano nie tylko Chopina. Także dwie młode śpiewaczki, które zechciały mu w koncercie towarzyszyć i dyrygenta, Carla Solivę. Trudno to sobie dzisiaj wyobrazić, ale wykonanie Koncertu e-moll nie odbyło się bez - dyktowanego zwyczajem epoki - intermezza. Otóż po odegraniu Allegra i zebraniu «hucznych braw» pianista ustąpić musiał miejsca śpiewaczce [ «ubranej jak aniołek, na niebiesko»], Anetce Wołkow. Odśpiewała arię Solivy i dopiero po tym mógł kompozytor wrócić do fortepianu, by odegrać Larghetto i Rondo. Drugą ze śpiewaczek była Konstancja Gładkowska. «Biało, $\mathrm{z}$ różami na głowie, do twarzy prześlicznie ubranej $[\ldots] \gg \ldots$ «Pożegnalnym» nazwano ów jesienny, październikowy koncert, który odbył się na siedem tygodni przed wybuchem Powstania, a na trzy przed opuszczeniem przez Chopina Warszawy. «Już kuferek do drogi kupiony, partycje poprawione, chusteczki do nosa obrąbione... Tylko się żegnać, a to najprzykrzej...»" [Tomaszewski 2020]. 
ale samolubną, niezdolną w pełni docenić wielkości talentu Fryderyka i siły jego uczuć do niej. Wydaje się zmęczona swą karierą i dlatego marzy jej się spokojna egzystencja, daleka od blichtru sceny i teatru. Fryderyk i Konstancja mówią innymi językami, żyją w dwóch różnych światach. On za chwilę wyjedzie z ojczyzny po sławę, a ona zostanie tu, w Królestwie Polskim, zrezygnuje z kariery śpiewaczki, która nie daje jej satysfakcji. Na pożegnanie Konstancja wręcza Fryderykowi białą różę, aby przypominała mu o ich niespełnionej miłości. Kobieta dobrze wie, że ich związek nie ma przyszłości, a ona jeszcze tylko przez chwilę będzie żyć we wspomnieniach kompozytora. Ich rozstanie okazuje się nieodwołalne. Na dalszy plan w tym akcie schodzą kwestie związków kompozytora z publicznością, zmuszonego do zaspokajania jej żądań i gustów. Z jednej strony Chopin jest uwielbiany przez słuchaczy, ale $z$ drugiej ciągle wypomina mu się, że nie napisał dotąd opery na miarę mistrzów włoskich czy niemieckich. W tekstach o charakterze popularnym, w których bohaterem jest artysta, uwaga autora zazwyczaj jest skupiona nie tyle na jego zmaganiach z materią twórczą, ile na walce $z$ bezdusznym otoczeniem, żądającym od niego pochlebstw i tworzenia według z góry narzuconych zasad. Artysta skazany przez filistrów na połowiczność, nędzę, walkę z pokusami i nałogami, a przede wszystkim na brak możliwości rozwoju swego talentu podejmuje rozpaczliwe próby znalezienia własnego miejsca w świecie sztuki [Poniatowska 2014: 180]. Najczęściej jest to człowiek stracony, który zmarnował własny talent. W sztuce Fleszarowej-Muskat zarówno Chopin, jak i jego otocznie widzą, że Fryderyk musi wyjechać z Warszawy do Paryża, ponieważ tylko tam ma szansę rozwinąć swój talent i zdobyć międzynarodową sławę. To przeświadczenie odzwierciedla się w słowach samego kompozytora: „Ale żebym naprawdę tutaj był czymś, trzeba mi Paryża” [Fleszarowa-Muskat 1965: 14].

Akt III ponownie rozgrywa się wieczorem w saloniku Chopinów. Rozmowy dotyczą sukcesu, który odniósł koncert Fryderyka, oraz zbliżającego się wyjazdu. Sztukę kończy rozmowa Fryderyka z Zuską, w trakcie której kompozytor zrozumie, że po wyjechaniu z Polski zyska sławę, ale utraci na zawsze to, co jest dla niego najcenniejsze: związek z ziemią rodzinną. 
FRYDERYK (nagle) Zuska, spójrz - jaki z tego okna widok na Warszawę, jaki księżyc domom dziwny pozór daje. Piękniejsze są jeszcze, niż za dnia. Lekkie jakieś, jakby chciały ulecieć z ziemi. Och, nigdzie na świecie noc nie zdobi tak miasta, jak tutaj - a oni mi stąd jechać każą... (pauza) A ty byś pojechała? [...] Więc nawet ty... nawet ty i nie mówisz, żebym został... Przecież powiedziałaś - tum się urodziła... Nawet ty! I nikt, nikt mi tego nie mówi... [...] Żeby ktoś jedno słowo rzekł... jedno słowo...

Kończy się zamyśleniem Chopina, gasi świece udając się na spoczynek i prosi Zuskę, aby nikomu o tej rozmowie nie mówiła. [Fleszarowa-Muskat 1965: 82-83]

W jednym ze swych listów Chopin tak z trwogą napisał o swoim wyjeździe do Francji: „Myślę, że jadę umrzeć” [Tomaszewski 2020]. Czas przed wyjazdem dla kompozytora okazał się trudny, pełen smutku, wahań, rozterek, co wpłynęło na odwlekanie decyzji. Chopin zdawał sobie bowiem sprawę z konieczności i nieodwołalności dokonanego wyboru. Do podróży namawiał go także adiutant ks. Konstantego, Siergiej Dmitriewicz Bezobrazow, meloman i wielbiciel jego muzyki. Wybitna jednostka nie ma szansy na rozwój swego talentu w niewoli, żyjąc w ciągłym zagrożeniu ze strony zaborcy.

Ważną funkcję w tym dramacie pełni tło historyczne, dzięki czemu widz może lepiej zrozumieć decyzję Fryderyka. Jego wyjazd nie jest ucieczką, tylko koniecznością uwarunkowaną sytuacją w Królestwie Polskim jesienią 1830 roku. Koniec lat 20. XIX wieku był czasem odrodzenia duchowego społeczeństwa w Królestwie Polskim, ale teraz właśnie się skończył. Z jednej strony nastąpił znaczący wzrost napięcia i nastrojów niepodległościowych, z drugiej prześladowań polskich patriotów przez władze rosyjskie. W rozmowach bohaterów dramatu pojawiają się znaczące wzmianki o trudnej sytuacji w Warszawie, o represjach wobec patriotów, rewizjach i aresztowaniach. Mowa jest o miejscu spotkań patriotycznie nastawionej młodzieży w Café Brzezińskiej na ul. Koziej, Szkole Podchorążych, więzieniu w klasztorze Karmelitów i mieszkaniu Joachima Lelewela. Z tego powodu ostrzeżenie 
Bezobrazowa nie wydaje się bez pokrycia i brzmi jak groźba. Nie wiadomo, jaki los spotkałby Fryderyka, gdyby zdecydował się pozostać w Warszawie. Być może podzieliłby dolę przyjaciół osadzonych w więzieniu u karmelitów.

Tak więc w dramacie Fleszarowej-Muskat wątek artystowski wiąże się ściśle $\mathrm{z}$ patriotycznym. W treść sztuki wpisana została dyskusja na temat polskiego losu, narodowej tożsamości, zarówno w wymiarze wyborów jednostkowych, jak i wspólnotowych. Pisarka uzasadnia ją poprzez akceptację określonej wizji tradycji romantycznej odczytywanej w kontekście walk narodowowyzwoleńczych, martyrologii i heroizmu. Historia interpretowana $\mathrm{w}$ duchu romantycznego idealizmu prezentuje się w tym tekście jako objawienie losu zarówno jednostki, jak i wspólnoty. Dlatego tak ważne są tu odwołania historyczne, ponieważ pozwalają na połączenie idei zawartej w muzyce Chopina z ideą wolności Ojczyzny. To z kolei pociąga za sobą realizację haseł „wybicia się na niepodległość” oraz walki „za waszą i naszą wolność” i wpływa na formułę sztuki narodowej.

W Ostatnim koncercie Fleszarowa-Muskat stworzyła własny styl dramaturgiczny, dzięki czemu opowieść biograficzna o Chopinie z dziedziny dokumentu i fikcji przesuwa się w kierunku opowieści legendowej czy mitycznej. Do rangi mitu pisarka starała się podnieść problem naczelny, którym jest wywodzący się z romantyzmu topos: artysta i świat. Za pomocą struktur i narzędzi charakterystycznych dla literatury popularnej mity przekształcają się w legendy, a te z kolei ulegają dość szybko petryfikacji w stereotypy i klisze, co pozwala na stabilizację obrazu świata i promowanie określonej wizji przeszłości, możliwej do interpretacji zgodnie z wyznacznikami Mickiewiczowskiego mesjanizmu. Legenda daje fundament do zbudowania wspólnoty narodowej, której jest także spoiwem. Trzeba jednak wziąć pod uwagę, że Fleszarowa-Muskat skierowała swój dramat do mniej wyrobionego odbiorcy, którego z reguły nie interesują innowacyjne eksperymenty ani gra intelektualna, ceni sobie natomiast przystępność, uznając ją za prymarną wartość danego tekstu. Zabieg ten jest dobrze widoczny w opisywanej sztuce. Tłumaczy, dlaczego bardziej niż konflikt ze światem zewnętrznym pisarkę interesuje osobowość twórcy i sposób percepcji przez niego 
świata. Chopin w ujęciu Fleszarowej-Muskat jawi się jako geniusz uczucia. Został obdarzony przez los niezwykłą charyzmą, ma spełnić dziejową misję: pobudzić naród do czynu wolnościowego. Jego muzyka staje się dla tego narodu pogrążonego w niewoli źródłem siły duchowej. Przez identyfikację z nią naród może rozpoznać się w „jestestwie” swoim, zyskać samowiedzę, samoświadomość i dzięki temu nową, silną tożsamość. Chopin w kreacji Fleszarowej-Muskat nie jest bynajmniej artystą ogarniętym szałem twórczym i stojącym „poza dobrem i złem”, jak ten z mrocznych wizji Stanisława Przybyszewskiego (Chopin und Nietzsche). W Ostatnim koncercie charakteryzuje go wysoka wartość moralna. Siła jego muzyki nie ma swych źródeł w ciemnej stronie ludzkiej psychiki, tylko w tym, co polskie, utożsamiane $\mathrm{z}$ tym, co ludowe - $\mathrm{w}$ mistycznym poczuciu łączności z ziemią rodzinną, a więc $\mathrm{w}$ tym, co stanowi entelechię narodu, rozumianą zgodnie ze słowami poematu Norwida: „I była w tym Polska - od zenitu / Wszechdoskonałości dziejów / Wzięta tęczą zachwytu - - / Polska - przemienionych kołodziejów! [wyróż. - M.O.]" [Norwid 1983: 498]. Muzyka Chopina staje się więc wcieleniem tak rozumianej polskości. A zatem jest to muzyka $\mathrm{z}$ ducha narodowa. Materializuje to, co żyje w podświadomości narodu, i stanowi syntezę doświadczeń życia narodowego. Wskazuje na to chociażby Fantazja A-dur na tematy polskie op. 13 skomponowana na fortepian i orkiestrę w roku 1828.

W Ostatnim koncercie genialna muzyka Chopina za pomocą dźwięków wyraża to, co w narodzie jest najdoskonalsze - istotę polskiej duszy: jej szlachetność, piękno i wielkość. Dla Fleszarowej-Muskat Fryderyk jest nie tylko genialnym artystą muzykiem, ale również patriotą, mocno zaangażowanym w sprawę Ojczyzny. Pisarka zdecydowanie promuje ideę patriotycznej interpretacji muzyki Chopina. Jest przekonana, że źródeł jego artystycznego geniuszu należy doszukiwać się w ścisłych, wręcz miłosnych związkach kompozytora z ziemią rodzinną. Chwila „uroczysta” (określenie Fryderyka Hebbla) jest wspólna dla jednostki genialnej (Chopin) i narodu (Polska). Pisarka w swym dramacie mówi o losie wspólnoty narodowej w przełomowym dla niej momencie. Zgodnie $\mathrm{z}$ takim odczytaniem ostatecznie to zaklęta w muzyce Chopina idea patriotyzmu w swym wariancie heroicznym, zbudowana na 
fundamencie etycznym, znajdująca uzasadnienie dla siebie w micie prometejskim, uznanym przez Fleszarową-Muskat za przekaz jednej z podstawowych wartości, organizuje jej dramat pod względem treści, formy i stylu. W ten sposób, promując określoną wizję polskości w duchu bohaterskim, insurekcyjnym i martyrologicznym, ujętym w słowa gloria victis, doszukując się w dziele Chopina wątków patriotyczno-rodzimych, utrwala i estetyzuje w Ostatnim koncercie romantyczny mitologem. W podobnym, idealistycznym stylu o Chopinie i jego muzyce pisał Juliusz Kaden-Bandrowski. Jego wypowiedź może stać się dobrym komentarzem do dramatu Fleszarowej-Muskat:

Przed nową burzą dni listopadowych odfrunął z Polski Chopin, a potem już do końca życia plynął z falą powstańczą przez ziemie Europy, na szkarłatach onej fali tragicznej przedziwny kwiat, w którym zamknięta była tajemnica nowej muzyki świata.

Czegoż się w Polsce nauczył, czegoż doświadczył? Naszego towarzyskiego obyczaju zaznał, dziwnego obyczaju tamtych czasów między zgrozą rzeczywistości a stylem empirowym rozpieszczonego romantycznie, zaznał opieki nauczycieli, bezradnych przecież wobec takiego geniuszu, zaznał serca przyjaciół i jakiejś młodocianej miłości.

Z tych pierwszych doznań młodości i z kawałeczka polskiej ziemi pomiędzy Żelazową Wolą a Warszawą umiał wysłuchać wszystko. Wszystko, czym cała Polska tchnęła w powabie pieśni i tańca od setek lat. Już wtedy przecie jako kilkunastoletni młodzieniec uwoził z sobą dwa swoje koncerty fortepianowe, dzieła, od których głębi po dzień dzisiejszy truchleją serca, dzieła, których czar niepożyty szumi zawsze skrzydłami młodości.

Tych dwu koncertów już by starczyło, by się takie czarnoksięstwo dokonało, że naród cały piękną karteczką nut szopenowskich duszę swą światu objawił i zaraz zwyciężył jakże szczytnym zwycięstwem: niczego nikomu nigdzie nie odbierając wszystkiemu wszędzie dał siłę nową, tak młodą, iż czerpią z niej już sto lat wszyscy najwięksi i końca młodości tej nie widać i zdaje się, jakby na wieki owa młodość 
szopenowska wszystkie inne, przyszłe, choćby najdalsze już w sobie pomieściła. [...]

I tak to było zawsze, wszędzie, ze wszystkim, czego tknął: tu Ojczyzna, tu znów epoka współczesna, tu świat, a tu on, Chopin, i przy krwawiącym boku najdroższej Ojczyzny, i wśród epoki rozsrożonej piorunem Beethovena, i na świecie roztrzęsionym od nowych praw, Chopin zawsze najbliżej tego wszystkiego a zarazem najdalej lecący naprzód. Więc tu, blisko, przy Ojczyźnie, w epoce i na świecie, a zarazem nieustannie gdzie indziej! Gdzie? Na dalekim progu nieśmiertelności. [Kaden-Bandrowski 1938: 8-10]

Według Kadena-Bandrowskiego (powielają tę koncepcję także Wierzyński, Iwaszkiewicz, Broszkiewicz) to od geniuszów, takich jak Chopin, płyną twórcze impulsy aktywizujące naród do czynu duchowego. To z kolei może doprowadzić go do twórczej transformacji, jego „przeanielenia”, o którym marzył Słowacki. Tak o tym pisze Kaden-Bandrowski:

[...] była w tym geniuszu wiedza spraw wyższa od tej, którą posiedli inni. Wiedza, która czyniła, że choć współczuł jak inni, że choć tak samo cierpiał nad sprawami ziemskimi, przetwarzał je, zwyciężał i zanosił na takie wyżyny, z których nie widać prawie celów doczesności, lecz wieczność się rozściela, radosna ze wszystkiego, co żyje. Polska dała mu ziemię natchnienia, dała mu ziarno dźwięku, ale tony, które Chopin z tej ziemi wyprowadził, stały się już uczuciem powszechnego człowieczeństwa. Zaprawdę, im bliżej przy nas trwał, tym dalej i tym wyżej uchodził od nas i dlatego mamy go w sercach naszych na zawsze, żeśmy wielkości jego nigdy ogarnąć nie mogli. [Kaden-Bandrowski 1938: 10-11]

A zatem w Ostatnim koncercie otrzymaliśmy przede wszystkim opowieść o wybitnej jednostce: genialnym artyście i polskim twórcy. Zaprezentowany został jeden z epizodów jego złożonej biografii: moment pożegnania z czasem dzieciństwa i młodości i przekraczania „smugi cienia”. Młodość Chopina okazuje się 
czasem dojrzewania i kształtowania jego artystycznej osobowości, podobnie rozumieli ją romantycy. Fleszarowa-Muskat powtarza w omawianym dramacie przekonanie wielu biografów Chopina, że indywidualność kompozytora została ukształtowana jeszcze przed jego wyjazdem na stałe z Warszawy, a więc przed 20. rokiem życia. Podzielała tym samym twierdzenie m.in. Wierzyńskiego, że właśnie ten czas dał artyście niezbywalną siłę kreacyjną. Pisze jednak nie tylko o geniuszu Chopina, ale także o powinności artysty wobec społeczeństwa, o potrzebie wsłuchiwania się przez niego w głos swego czasu i o konieczności życia sprawami narodu, aby stworzyć dzieło, które pobudzałoby tkwiące w narodzie uczucia, budowało narodową wspólnotę. W ten sposób w Ostatnim koncercie na plan pierwszy wysunęła kwestię patriotyczną, ową silną więź Chopina z Polską, czyniąc z niego narodowego geniusza.

Omawiany utwór tylko pozornie jest więc dramatem opartym na schemacie biograficznym. W rzeczywistości to wszystko, co składa się na dramat, czyli konflikt, układ fabuły, kompozycja czasu i przestrzeni, typy bohaterów i motywacja ich zachowań, styl ich wypowiedzi - zaprojektowane jest przez pisarkę tak, aby mogło dojść do wtajemniczenia w życie zbiorowe. Rewolucyjność muzyki Chopina polega na tym, że - według Fleszarowej-Muskat - sublimuje i wyraża ona pragnienia wolnościowe Polaków, co przekłada się na koncepcję narodowej sztuki. Jest to muzyka przesycona ekspresją i pierwiastkiem narodowym. Można zatem stwierdzić, że pisarka wykorzystała epizod z życia kompozytora, aby stworzyć tekst o Polsce i polskości.

Jednak na powyższych rozważaniach nie wyczerpuje się analiza Ostatniego koncertu. To, że nie jest to tekst bardzo skomplikowany i wielowarstwowy, nie oznacza, iż mamy do czynienia z banalizacją problematyki. Fleszarowa-Muskat, podobnie jak Nowaczyński, odchodzi od monumentalizacji postaci kompozytora. Literatura popularna pokazuje człowieka głównie $\mathrm{w}$ interakcjach $\mathrm{z}$ innymi osobami [Poniatowska 2014: 182], a to przecież stanowi zasadę konstrukcyjną dramatu. Postać Chopina pojawia się w rozmowach różnych osób. Również jemu zostaje udzielony głos. Jego sylwetka, rzec można, wyłania się z dialogów i sytuacji zaprezentowanych na scenie. Ważną rolę w tej sztuce odgrywa przede wszystkim słowo, 
czego dowodem jest poniższy cytat pochodzący ze sceny z aktu II, prezentującej spotkanie i rozmowy toczone przez bohaterów w przerwie koncertu. Dopiero dłuższy fragment pokazuje efekt naturalności, jaki udało się uzyskać Fleszarowej-Muskat, która, jak się okazuje, potrafiła znakomicie operować słowem, aby udramatyzować sytuację:

P. JUSTYNA Co to? Dla kogo te kwiaty?

FRYDERYK (mieszając się) To? To nic... To pewnie dla... panien...

LUS (wchodząc - Od trzeciego planu) Frycek! Jesteś u wszystkich na ustach! Nawet byś nie uwierzyl, gdybyśmy ci wszystkie komplimenta Powtórzyć mieli.

ANTONI Wiluś twierdzi, że Adagio najwięcej efektu zrobiło, podług mnie nic z Rondem równać się nie może a ksiądz Cybulski Allegro na pierwszym miejsc ustawia. (kroki dragonów oddalają się)

WILUS (na pierwszym planie - zmienionym głosem) Linowski i Łęczyński w więzieniu Karmelitów. Dziś w nocy ich wzięli.

FRYDERYK Skąd wiesz?

WILUŚ Wyobrażasz sobie swój koncert bez Linowskiego?

Przecież nuty ci przepisywal. Zapytałem o niego, przy sposobności powiedziano mi i o Łęczyńskim.

ANTONI Dziś wyszedł zakaz dla uczniów Aplikacji i podchorążych chodzenia do cafehauzów. OSKAREK (wpadając) Masz Frycek wieniec...!

FRYDERYK (w roztargnieniu ) Od Moriolki. (pauza)

Czego oni się boją?

WILUŚ Jeszcze nie czas, żeby usłyszeć odpowiedź na to pytanie.

P. JUSTYNA (pośpiesznie) Fryderyku, tobie odpocząć trzeba! Jeszcze dzisiaj grać musisz! Zuska! Kawa dla panicza! ZUSKA Przecież jest w filiżance. Całkiem zimna! P.JUSTYNA No, napij się! Napij się chociaż tyk! FRYDERYK (pije) Linowski! W głowie mi się nie mieści! Jeszcze wczoraj z nim rozmawiałem! 
OSKAREK (zadyszany i przejęty - wota od wejścia) Frycek!

Wiesz, kto jest na sali? Pan minister...

WILUS (przerywa mu) Cicho bądź! (Oskarek

skonfundowany milknie)

FRYDERYK (w zamyśleniu) Linowski musiał się w co wdać.

Na pewno musiał się W co wdać. Widywałem go prawie co dzień - i z niczym się nie zdradził... Dlaczego? Dlaczego

mnie się odsuwa? Nie mówi?

P.MIKOŁAJ I WILUS Fryderyku!

FRYDERYK (histerycznie) Dlaczego?

OSKAREK (z trzeciego planu) Frycek! Przecież te kwiaty, co tu stoją to dla ciebie!

FRYDERYK (nie rozumiejąc) Co?

OSKAREK Te kwiaty! Te wszystkie kwiaty!

FRYDERYK (nie dowierzając, ostrożnie) Kto przysyła?

OSKAREK Pan Bezobrazow.

LUDWIKA Pokaż! (podbiega - pauza) Bezobrazow!

P.MIKOŁAJ On?

LUDWIKA Zaszczyt niespodziewany! Zwiózł tu pół oranżerii.

IZIA Gdzie my to w domu pomieścimy?

ZUSKA A pójdę jutro na Plac Zamkowy i sprzedam

P. JUSTYNA Zuska!

ZUSKA A mało by pieniędzy było?

WILUS Ani się spodziewałeś, że takiego honoru dziś dostąpisz. Pan Fliigel adjutant Bezobrazow, znawca muzyki rzadki, coneseur co się zowie (urywa, zmieszany) (kroki, dźwięk ostróg)

BEZOBRAZOW (z trzeciego planu) Panie Chopin! Drogi panie Chopin! Wahałem się, czy przyjść do pana. Nie chciałem zakłócać panu odpoczynku i chwili wytchnienia z drogimi mu osobami. Ale moje uwielbienie dla pana, mój podziw dlatego, co pan stworzył - kazały mi przełamać te względy. Musiałem panu osobiście podziękować za dzisiejszy wieczór. Za to, że pan jest, że pan gra, że pan żyje... 
FRYDERYK Pan mnie wymowny zaszczyt czyni, panie

Bezobrazow.

BEZOBRAZOW Nie, nie - niech pan nic nie mówi! Nic $\mathrm{z}$ tego, co się odpowiada na grzeczne komplimenta. Ja z nimi tutaj nie przyszedłem. Pana skromność jest powszechnie znana. Pan sam może jeszcze nie wie, co to znaczy być Chopinem. A inni przeczuwać to dopiero mogą. [Fleszarowa-Muskat 1965: 47-48]

W rozmowach zgromadzonych tu osób przeplatają się zarówno sprawy ważne, jak i nieistotne. Pisarka nie budowała dramatu o charakterze alegorycznym czy parabolicznym, a wykreowany przez nią świat można uznać za realistyczny. Realizm osłabia potencjalną koturnowość tematu, sztuczność czy też egzaltację zagrażające autentyczności obrazu scenicznego. Pisarka znakomicie operuje realiami epoki. Jest to świat prawdziwy, pachnący poranną kawą i bułkami, w którym ważną rolę odgrywa podróżny kuferek i pasta do butów, a także fortepian. Tak sobie ten świat młodości Fryderyka wyobraziła i w taki sposób go wykreowała na scenie.

\section{Bibliografia}

Boniecki Edward (1991), Jak pisać o Chopinie? Wokót kontrowersji

Szymanowski - Iwaszkiewicz, „Ruch Literacki”, nr 6, s. 681-693.

Burek Tomasz (1987), Żadnych marzeń, Polonia Book Fund Ltd.,

Londyn.

Cieśla-Korytowska Maria (2004), Aneks, w: tejże, Romantyczne

przechadzki pograniczem, Universitas, Kraków, s. 229-364.

Dec Agata (1992), Kilka uwag o powieści-flądrze na młodopolskim rynku

czytelniczym, „Literatura i Kultura Popularna”, z. 2/3, s. 67-75.

Fleszarowa-Muskat Stanisława (1960a), Ostatni koncert

[dramat w 3 aktach], [słuchowisko].

Fleszarowa-Muskat Stanisława (1960b), Ostatni koncert

[dramat w 3 aktach], „Dialog”, nr 7, s. 40-46.

Fleszarowa-Muskat Stanisława (1965), Ostatni koncert

[dramat w 3 aktach], Ludowa Spółdzielnia Wydawnicza, Warszawa.

Hejmej Andrzej (2010), Chopin i jego muzyka

$w$ literaturze, [dostęp: 1 grudnia 2010],

http://www.chopin.pl/chopin_w_literaturze.pl.html. 
Kaden-Bandrowski Juliusz (1938), Życie Chopina, Gebethner i Wolff, Warszawa.

Korotkich Krzysztof (2020), Kwaśne pomarańcze „W Biatymstoku”. O mało popularnym wierszu Agnieszki Osieckiej, [dostęp: 15 grudnia 2020], https://tinyurl.com/kzk6psn8.

Kubikowski Zbigniew (1965), Bezpieczne, małe mity, Ossolineum, Wrocław.

Kuźma Erazm (1994), Literatura popularna a literatura wysokoartystyczna, „Literatura i Kultura Popularna”, nr 45 (1621), s. 78-81.

Lichański Jakub Z. (2014), Badania literatury popularnej. Tezy, w: Literatura i kultura popularna. Badania i metody, red. Anna Gemra, Adam Mazurkiewicz, Pracownia Literatury i Kultury Popularnej oraz Nowych Mediów, Wrocław, s. 21-45.

Maciąg Kazimierz (2010), „Naczelnym u nas jest artysta”. O legendzie Fryderyka Chopina w literaturze polskiej, Wydawnictwo Uniwersytetu Rzeszowskiego, Rzeszów.

Mitosek Zofia (1974), Literatura i stereotypy, Ossolineum, Wrocław. Norwid Cyprian (1983), Pisma wybrane, t. 1, wybrał i objaśnił Juliusz Witold Gomulicki, pIw, Warszawa.

Nowaczyński Adolf (1948), Młodość Chopina, Czytelnik, Warszawa. Poniatowska Irena (2001), Historyczne przemiany recepcji Chopina, w: Chopin - w poszukiwaniu wspólnego języka. Materiały z konferencji, red. Artur Szklener, NIFC, Warszawa, s. 37-52.

Poniatowska Izabela (2014), Modernizm bez granic. Wielkie tematy nowoczesności w polskich powieściach popularnych drugiej połowy XIX wieku, Wydawnictwo Wydziału Polonistyki Uniwersytetu Warszawskiego, Warszawa.

Schaff Adam (1981), Stereotypy a działanie ludzkie, Książka i Wiedza, Warszawa.

S.J. (1968), Stanisława Fleszarowa-Muskat. Sylwetki, „Nowe Książki”, nr 18, s. 4 .

Stołek-Nawrocka Mariola (2009), Kolska pisarka. Twórczość Stanisławy Fleszarowej-Muskat, Wystawy i Wydawnictwo K.K. im. Zdzisława Krzyszkowiaka, Warszawa.

Świerkosz Krystyna (2014), Na fali. Portret biograficzny Stanistawy Fleszarowej-Muskat, Oskar, Gdańsk.

Tarnowski Stanisław (1892), Chopin i Grottger. Dwa szkice, Księgarnia Spółki Wydawniczej Polskiej, Kraków.

Tomaszewski Mieczysław (2020), Cykl audycji „Fryderyka Chopina Dzieła Wszystkie", Polskie Radio Program II, [dostęp: 1 grudnia 2020], https://pl.chopin.nifc.pl/chopin/composition/detail/page/2/id/47. 
Maria Jolanta Olszewska

\section{The National Genius, or a Portrait of Frédéric Chopin in Ostatni koncert by Stanisława Fleszarowa-Muskat}

The drama Ostatni koncert (The Last Concert) (1960) by Stanisława Fleszarowa-Muskat, originally written as a radio play, sits on the border between popular and fictional literature. The text was intended for a wide audience. The plot focuses on a single event - Frédéric Chopin's last concert in Warsaw, just before his departure to France, which took place on October 11, 1830. Youth, as it was understood by the romantics, turns out to be a time that shaped Chopin's artistic personality. In this drama, the independence background is important as it highlights Chopin's ties to the fate of his homeland, which gives his music a patriotic and revolutionary dimension. In sounds, Chopin's brilliant music expresses the essence of the Polish soul: its nobility and love of freedom. Chopin's concert took place at a turning point both for the composer and for the nation whose spirit he expressed through sounds. The drama about Chopin, the national genius, is at the same time a drama about a national community that acquires its identity by identifying with his music.

Keywords: music; concert; love; uprising; Polishness; folklore; nation; homeland.

Maria Jolanta Olszewska - historyk i literaturoznawca, profesor. Członek Pracowni Historii Dramatu 1864-1939 przy Instytucie Literatury Polskiej, TN KUL i Stowarzyszenia im. Stefana Żeromskiego. Główne zainteresowania naukowo-badawcze: historia literatury XIX i Xx wieku, genologia, szczególnie pogranicze literatury i gatunków użytkowych, historia świadomości polityczno-społecznej społeczeństwa polskiego i jej odzwierciedlenie w literaturze drugiej połowy XIX wieku, dzieje dramatu i teatru w drugiej połowie XIX i pierwszej połowie xx wieku. Interesuje ją analiza wybranych, często zapomnianych dziś utworów literatury polskiej XIX i Xx wieku. Autorka m.in. następujących publikacji: „Tragedia chłopska”. Od W.L. Anczyca do K.H. Rostworowskiego. Tematyka - kompozycja-idee (2001), Człowiekw świecie Wielkiej Wojny. Literatura polska z lat 1914-1919 wobec I wojny światowej. Wybrane zagadnienia (2004), Studenci z Królestwa Polskiego przed powstaniem styczniowym. Glosa do „Lalki” Bolestawa Prusa (2004), W poszukiwaniu sensu. Szkice o literaturze polskiej XIX $i \mathrm{XX}$ wieku (2005), Heroizm ludzkiego istnienia. $W$ kregu wybranych zagadnień etycznych $w$ literaturze polskiej II połowy XIX i I połowy $\mathrm{xx}$ wieku. Szkice (2007), W kręgu meteorologii i astronomii Stownictwo pism Stefana Żeromskiego, t. 10 (2007), Drogi nadziei (2009), Stefan Żeromski. 
Spotkania (2015), Spór o przyszłość literatury polskiej, czyli polemiki ze Stefanem Żeromskim po jego odczycie "Literatura a życie polskie” (2019), Wojna polsko-bolszewicka $w$ literaturze polskiej (2020); artykułów w tomach zbiorowych i czasopismach, współredaktorka kilku wydań zbiorowych. Adres e-mail: mj.olszewska@uw.edu.pl. 